\title{
KREATIFITAS MELALUI BATIK CAP DARI KARTON BEKAS PADA SISWA DISABILITAS
}

\author{
Dini Yanuarmi \\ Widdiyanti \\ Sri Sundari \\ Prodi Seni Kriya Fakultas Seni Rupa dan Desain \\ Institut Seni Indonesia Padangpanjang \\ dinitekstil@gmail.com
}

\begin{abstract}
ABSTRAK
Tujuan kegiatan pengabdian masyarakat ini adalah untuk memberikan pengetahuan (knowledge) dan keterampilan (skill) pada penyandang disabilitas khususnya di Sekolah Luar Biasa Negeri 1 Padangpanjang. Pelatihan ini juga sebagai upaya untuk mempertahankan dan melestarikan keberadaan batik sebagai seni tradisi dan warisan budaya.. Membatik teknik cap dari karton bekas diharapkan dapat membekali siswa dengan kemampuan dan keahlian sehingga mereka memiliki bekal keterampilan, dan dapat membantu meningkatkan, mengembangkan sikap, pengetahuan sebagai pribadi maupun anggota masyarakat dalam mengadakan hubungan timbal balik dengan lingkungan sosial, budaya dan alam sekitar. Metode dilakukan secara dua tahap, yaitu demonstrasi dan praktek. Praktek dimulai dengan membuat desain motif yang diaplikasikan pada canting cap, dilanjutkan membatik dengan teknik cap. Hasil yang dibuat berupa taplak meja dan tas, dengan desain motif dibuat sesuai kreasi dari para siswa. Keterbatasan tidak menjadi penghalang mereka dalam berkreatifitas, namun sebaliknya mereka memiliki kemampuan dalam berolah rasa, karsa dan cipta. Terlihat dari canting cap yang dihasilkan dengan desain yang kreatif dan inovatif.
\end{abstract}

Kata Kunci: batik; disabilitas; kreatifitas. 


\section{PENDAHULUAN}

Batik sebagai bagian dari budaya tradisi memiliki dua teknik, batik tulis dan batik cap. Batik tulis yaitu pembuatan batik dilakukan dengan menggunakan alat berupa canting untuk menuliskan lilin batik di atas permukaan kain yang sudah dibuat corak berupa motif. Batik cap yaitu dalam prosesnya menggunakan alat berupa cap seperti stempel yang terbuat dari tembaga. Kedua teknik tersebut masih tetap bertahan di tengah pesatnya perkembangan industri tekstil dewasa ini. Perbedaan di antara keduanya adalah dari proses pemindahan lilin batik pada kain, yaitu dengan media canting dan cap. Pengerjaan batik dengan menggunakan canting lebih lama dibandingkan dengan cap.

Seiring perkembangan pengetahuan terhadap batik, cap batik yang awalnya dibuat dari tembaga, dapat dibuat dari bahan yang sederhana yaitu kertas. Kertas yang dapat digunakan adalah yang memiliki ketebalan seperti karton. Membuat cap batik dari karton lebih mudah dan praktis daripada cap yang terbuat dari tembaga, baik dari bahan maupun cara Hal 70 pembuatan.

Batik dengan menggunakan cap dari karton dirasa mampu dibuat oleh anak-anak penyandang disabilitas. Penyandang disabilitas yaitu mereka yang memiliki kekurangan fisik dan mental. Istilah tersebut bertujuan agar anak-anak dengan kekurangan fisik dan mental tetap memiliki kepercayaan diri, merasa memiliki nilai, memiliki semangat untuk maju dan tidak dilihat sebelah mata oleh masyarakat. Banyak pemikiran negatif mengenai mereka, namun hal tersebut bukanlah suatu yang diinginkan oleh mereka maupun keluarganya. Peran Sekolah Luar Biasa seperti yang telah diuraikan di atas yaitu setiap anak-anak memiliki hak untuk mendapatkan tumbuh kembang yang baik. Tidak saja di tengah keluarga, namun juga di tengah masyarakat dan negara. 
Berdasarkan pengalaman dalam pelatihan membatik terhadap Anak Berkebutuhan Khusus di SLB Mutiara Bunda pada tahun 2017, bahwa dengan keterbatasan yang mereka miliki hanya sebagian kecil yang mampu membatik dengan menggunakan canting, karena mencanting merupakan proses dalam membatik yang memerlukan kesabaran, dan ketelitian. Akan tetapi proses selain mencanting, seperti membuat desain motif, memindahkan desain ke kain dan pewarnaan dapat dipraktekkan dengan baik oleh peserta didik.

Pelatihan dilaksanakan di SLB N 1 Kota Padangpanjang terletak di Jl. M. Nazir Dt. Pamuncak Silaing Bawah Kecamatan Padangpanjang Barat Kotamadya Padangpanjang. Menurut Kepala Sekolah, sekolah ini berdiri pada tahun1984 dengan nama SDLB, dan pada tahun 2017 berubah status menjadi SLB N 1 Padangpanjang. Terdiri dari tiga tingkat pendidikan, yaitu SDLB, SMPLB, dan SMALB. Pada saat ini jumlah tenaga pengajar sebanyak 11 orang, sedangkan peserta didik seluruhnya berjumlah 67 orang. (Wawancara: Wahyudi, tanggal 26 Hal|71 Februari 2018)

Tujuan dilakukannya pelatihan, sesuai dengan tuntutan pendidikan di Indonesia sebagai bagian dari pembentukan budi pekerti, pendidikan dapat memberi kontribusi besar terhadap pembentukan jati diri, sikap dan mental terpuji yang berakar dari nilai-nilai budaya bangsa. Di dalam pendidikan terangkum unsur pengetahuan (knowledge), keterampilan (skill), dan sikap (attitude) yang terpadu dalam kreativitas dan kepribadian siswa. Proses pembelajaran agar peserta didik secara aktif mengembangkan potensi dirinya, kecerdasan, akhlak mulia, serta keterampilan yang diperlukan oleh diri mereka, masyarakat, bangsa dan Negara. Bertitik tolak dari tujuan tersebutlah setiap lembaga pendidikan, Sekolah Luar Biasa (SLB) bergerak dari awal hingga akhir sampai titik tujuan 
suatu proses pendidikan, yang pada akhirnya dapat mewujudkan terjadinya pembelajaran sebagai suatu proses aktualisasi potensi peserta didik menjadi kompetensi yang dapat dimanfaatkan atau digunakan dalam kehidupan.

Menurut Petunjuk Pelaksanaan Sistem Pendidikan Nasional tahun 1993, lembaga pendidikan SLB adalah lembaga pendidikan bertujuan membantu peserta didik yang menyandang kelainan fisik dan atau mental, perilaku dan sosial. Agar mampu mengembangkan sikap, pengetahuan dan keterampilan sebagai pribadi maupun anggota masyarakat dalam mengadakan hubungan timbal balik dengan lingkungan sosial, budaya dan alam sekitar. Selain itu, diharapkan dapat mengembangkan kemampuan dalam dunia kerja atau mengikuti pendidikan lanjutan.

Selain memiliki keahlian membuat batik, peserta didik juga memperoleh pembelajaran selama proses membatik. Dalam prosesnya membatik memerlukan sikap teliti, sabar dan telaten, sehingga peserta didik dengan keterbatasannya mendapatkan pembelajaran sikap Hal|72 secara tidak langsung. Proses yang dilakukan secara manual, melatih kepekaan rasa dan motorik peserta didik yaitu anak dengan kebutuhan khusus. Membatik dilakukan dengan beberapa tahapan, seperti yang diungkapkan oleh Aep S. Hamidin, batik berasal dari "amba" (Jawa) diartikan menulis, dan "nitik", merujuk pada teknik pembuatan corak menggunakan canting dan pencelupan kain, menggunakan bahan perintang warna yaitu malam/ lilin yang diapilkasikan di atas kain (2010: 7).

Batik sebagai salah satu bentuk kebudayaan yang adiluhung, diperkenalkan dan dilatih kepada peserta didik yang memiliki keterbatasan. Selain mendapatkan ilmu berupa keterampilan membuat batik, peserta didik juga ikut menjaga dan melestarikan kebudayaan masyarakat Indonesia. Menurut Dharsono bahwa, 
pada era globalisasi kita dihadapkan dalam dua persoalan pokok mengenai persoalan budaya, satu sisi dituntut untuk maju (progress), sisi lain dituntut untuk melestarikan warisan budaya yang telah mapan (konservatif). (2016: 91)

Peran Pendidikan Tinggi seni menjadi penting dalam mensukseskan kegiatan tersebut. Tri Dharma Perguruan Tinggi sebagai salah satu syarat kewajiban setiap tenaga pendidik berupa pengabdian pada masyarakat, diharapkan oleh Sekolah Luar Biasa (SLB) Mutiara Bunda memberikan bekal pelatihan dalam mempersiapkan peserta didiknya untuk memiliki pengetahuan dan keterampilan, sehingga peran sekolah dalam mensukseskan tujuan pendidikan yang menghasilkan peserta didik yang mandiri dapat terwujud.

\section{Metode}

Metode yang dilakukan dalam kegiatan pelatihan adalah diawali dengan penjelasan dan diskusi dengan peserta mengenai batik yang diarahkan pada batik teknik cap, perancangan (membuat desain) cap, proses pembuatan cap dari karton limbah, membatik teknik cap, pewarnaan dan Hal|73 fiksasi, melorod (menghilangkan lilin batik).

Membatik dilakukan dengan beberapa metode, di antaranya metode ceramah, demonstrasi dan latihan atau praktek langsung. Metode ceramah dan tanya jawab dilakukan dengan memberikan pengetahuan secara teoritis kepada peserta didik mengenai batik secara umum. Pengenalan terhadap peralatan dan bahan yang digunakan dalam membatik secara spesifik. Selain itu melalui metode ini juga diberikan arahan dan penjelasan mengenai peluang bagi peserta dalam meningkatkan potensi mereka ke arah yang lebih baik sebagai pemula.

Metode demonstrasi dan latihan dilakukan pada saat peserta didik memasuki tahapan proses (praktek). Metode ini juga penting karena untuk menguasai keterampilan secara teknis, peserta didik harus melaluinya secara 
bertahap. Metode ini dilakukan mulai dari awal sampai akhir, berurutan secara teknis, sehingga peserta pelatihan benar-benar menguasai

keterampilan membatik dengan baik.

Tahapan pelatihan diawali dengan membuat cap batik. Pertama membuat desain yang akan dijadikan cap batik, kedua membuat cap batik, ketiga membatik teknik cap, keempat proses mewarna. Setelah metode ceramah secara umum dan khusus diawali dengan latihan membuat desain motif untuk cap (motif daerah/ tradisi dan kreasi). Peserta memilih sendiri motif yang telah dipersiapkan sebelumnya, dengan mengubah sedikit bentuk motif sesuai kemampuan masing-masing peserta. Motif yang selesai dibuat, dipindahkan ke media cap dengan cara dijiplak. Tahapan dan proses dapat digambarkan seperti bagan berikut, 


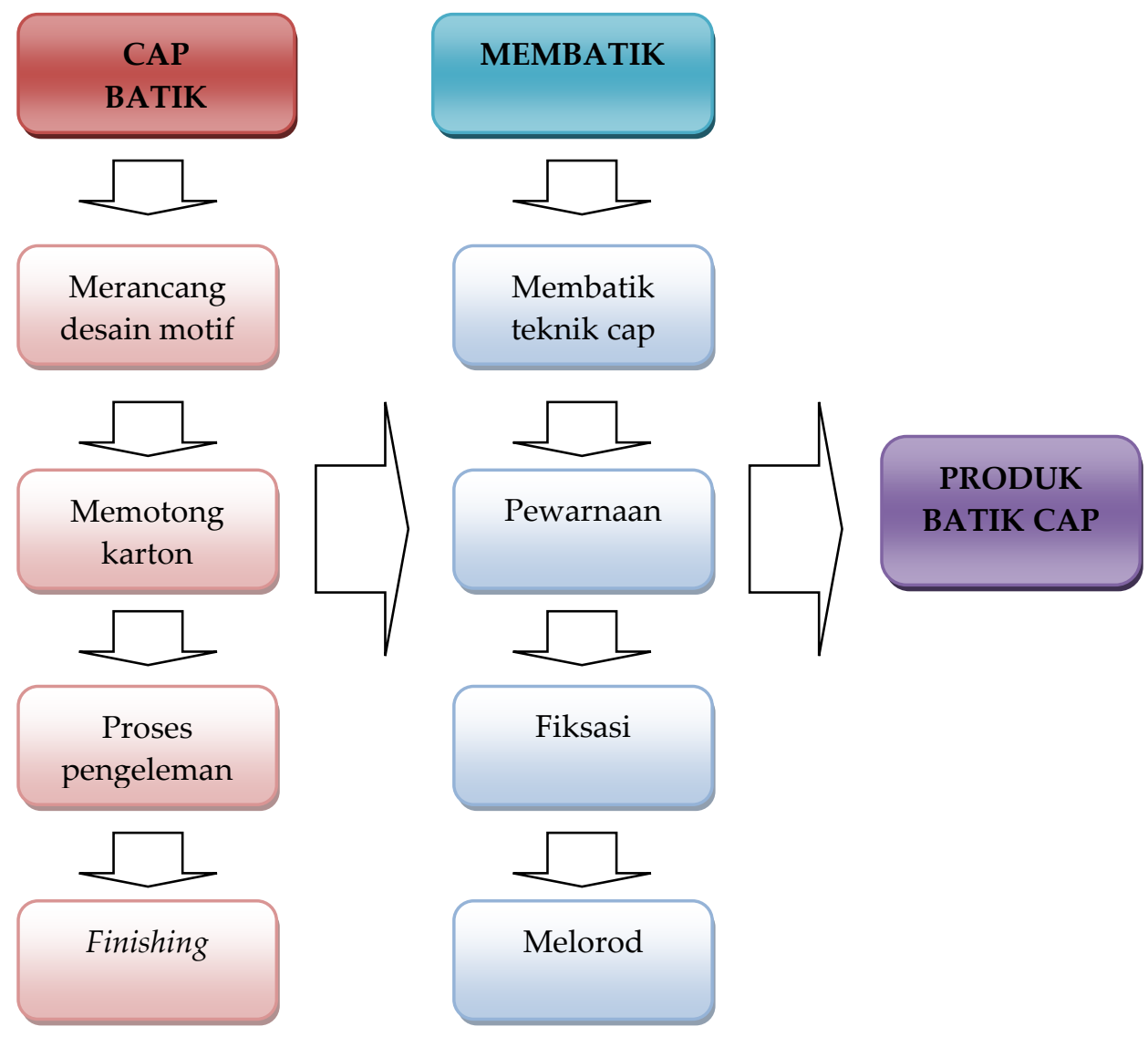

Gambar 1. Prosedur dan tahapan pelatihan

\section{PEMBAHASAN}

Pelatihan menghasilkan produk berupa cap batik dengan beragam motif dan batik seperti taplak meja dan tas. Motif yang dibuat berupa kreasi dari budaya alam Minangkabau dan kreasi peserta (disabilitas). Merujuk pada motif tersebut, tercipta produk batik yang kreatif dan inovatif. Meskipun bentuk motif yang dibuat disederhanakan

dengan

cara mengambil bagian tertentu saja. Namun tetap memperlihatkan bentuk asli untuk memelihara nilai luhur budaya daerah. Seperti yang diungkapkan oleh SP. Gustami kontinuitas dan perubahan seni kriya yang mengandung nilai luhur budaya bangsa akan tetap terpelihara dengan baik, apabila usaha pengembangannya 
didasarkan atas pemikiran yang rasional, kepekaan cita rasa estetik dan keyakinan iman yang kuat. (2008: 44) Alasan mendasar kenapa menggunakan motif tersebut adalah untuk tetap menjaga dan melestarikan budaya, selain untuk memberikan ciri khas terhadap produk yang dibuat. Inilah yang membedakannya dengan produk dari daerah lain meskipun dengan teknik yang sama.

Hasil nyata yang diperoleh dari kegiatan ini selain produk yang disebutkan di atas, juga berupa skill atau keterampilan bagi peserta pelatihan. Peserta memiliki kemampuan dasar dalam membuat produk dengan teknik batik tulis menggunakan pewarna teknik colet (lukis). Peserta diberikan bimbingan dan arahan membuat produk berupa taplak meja dan tas dimulai dari membuat desain motif. Bagaimana cara membuat desain dan penempatan motif yang baik. Dilanjutkan dengan membuat cap batik, dan cara mencap pada kain. Bagaimana cara pewarnaan supaya menghasilkan warna yang bagus dan rata sesuai dengan standar pewarnaan batik. Setelah mewarna adalah proses fiksasi (mengunci Hall 76 warna), peserta memahami proses ini dengan baik dan benar. Terakhir adalah proses melorod (menghilangkan lilin/ malam).

Membatik merupakan teknik menghias permukaan kain sehingga memiliki nilai estetis dan filosofis. Selain itu, proses pembuatan sehelai kain batik membutuhkan knowledge (ilmu) dan skill (keterampilan) dan attitude (sikap). Untuk menghasilkan kain batik adalah melalui beberapa proses atau tahapan, di mana masingmasing tahapan dan proses tersebut harus dibarengi dengan ketelitian, ketelatenan dan kesabaran. Setiap proses dalam membuat batik mengandung nilai-nilai pengajaran yang dapat diresapi oleh setiap orang yang membuatnya. Tidak hanya bagi orang yang memiliki kesempurnaan mental dan fisik, akan tetapi nilai-nilai tersebut menjadi suatu hal yang 
istimewa bagi mereka yang memiliki keterbatasan (disabilitas).

Pada pelatihan diawali dengan membuat cap batik, dan selanjutnya adalah proses aplikasi. Membatik menggunakan cap yang sudah diproduksi oleh peserta pelatihan. Adapun di antara cap batik yang dibuat dan sudah diaplikasikan seperti pada gambar berikut,
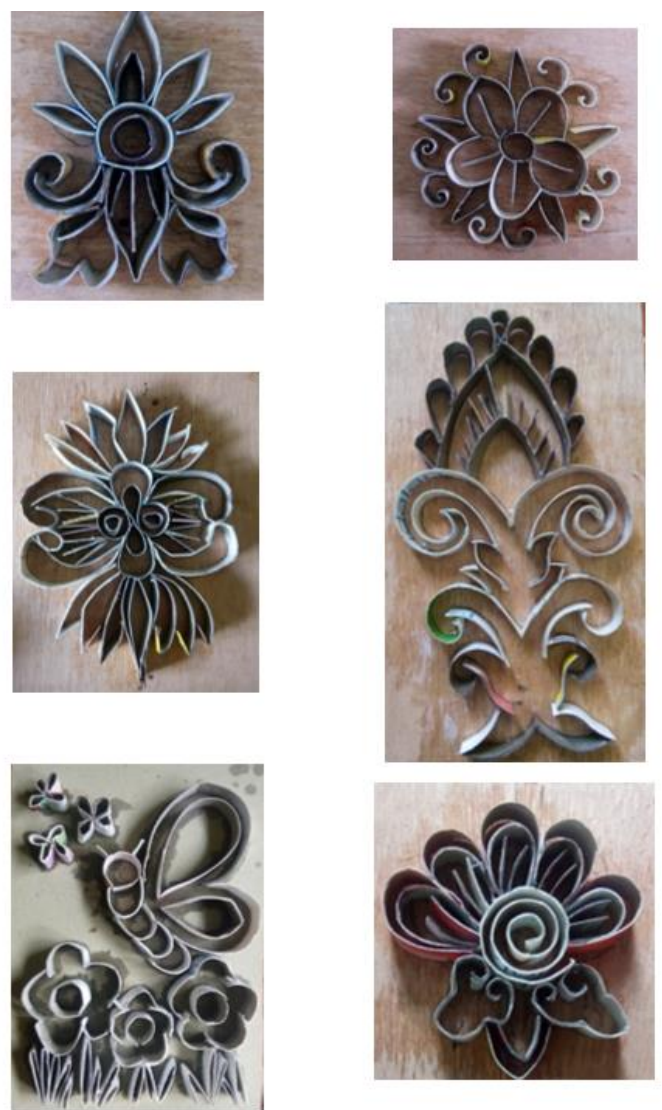

Gambar 2. Cap batik

(Foto: Dini, 2018)

Melalui kegiatan pelatihan memiliki kehidupan yang setara membatik dengan teknik cap, dengan orang normal pada umumnya. diharapkan dapat membekali mereka Hasil nyata yang diperoleh dari yang memiliki keterbatasan tersebut terutama dari aspek skill kegiatan ini selain produk yang disebutkan di atas, juga berupa skill (keterampilan). Dengan bekal keterampilan salah satunya batik, para atau keterampilan bagi peserta pelatihan. Peserta memiliki disabilitas memiliki modal dan kemampuan dasar dalam membuat kemampuan dalam menghadapi dunia produk dengan teknik batik cap kerja nantinya, sehingga mereka menggunakan pewarna teknik celup (naphtol) dan colet (remazol)). Peserta 
diberikan bimbingan dan arahan membuat produk berupa taplak meja dan tas, dimulai dari membuat desain motif. Bagaimana cara membuat desain dan penempatan motif yang baik. Dilanjutkan dengan membuat cap menggunakan potongan karton bekas sesuai dengan desain motif yang sudah dirancang masing-masing peserta, dan membatik teknik cap. Setelah selesai dibatik dilanjutkan mewarna dengan dua teknik pewarnaan, peserta memahami proses ini dengan baik dan benar. Terakhir adalah proses melorod (menghilangkan lilin/ malam).

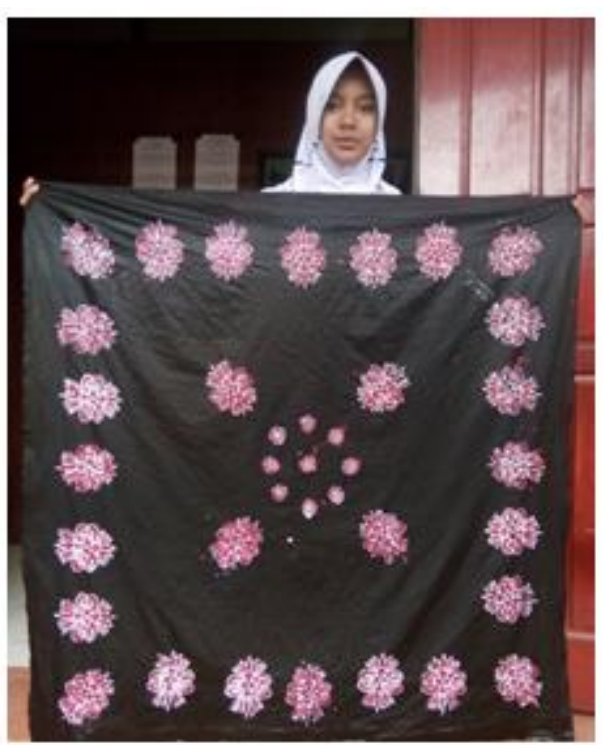

Gambar 3. Taplak meja teknik batik cap (Foto: Dini, 2018)

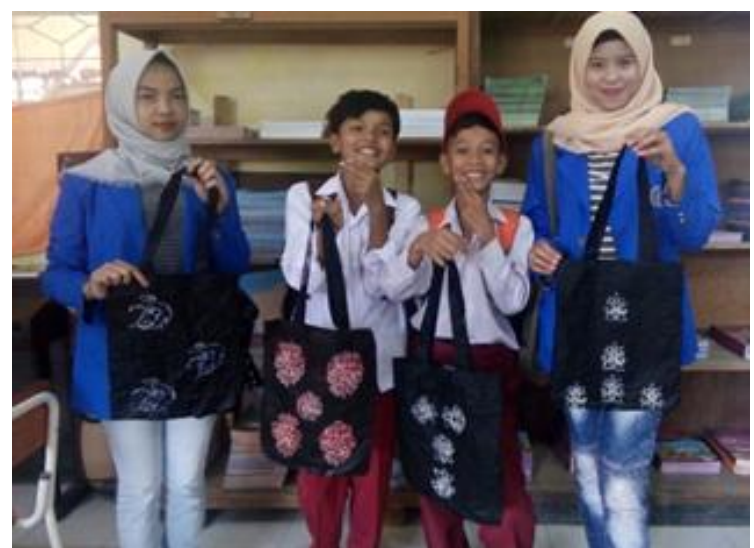

Hal| 78

Gambar 4. Tas teknik batik cap

(Foto: Dini, 2018)

Pengetahuan, Keterampilan, Sikap dan Rangsangan Motorik

Pelatihan terhadap anak yang yang ditujukan sebagai bekal keterampilan dan keilmuan, ternyata mendapat apresiasi yang luar biasa. Membatik merupakan sesuatu yang baru, dikarenakan belum pernah dikenalkan sebelumnya. Tentu saja hal ini menjadi motivasi dalam proses transfer ilmu terhadap mereka. Kemauan dan keingintahuan terhadap batik sehingga memiliki sikap sabar, telaten dan tanggungjawab.

Adapun hasil yang dicapai dalam proses membatik ini adalah peserta dengan keterbatasan yang dimiliki dapat merangsang motorik 
secara bertahap, sesuai dengan proses dalam membuat batik. Selain juga dapat melatih sikap (attitude), artinya bahwa dalam proses membatik melalui beberapa tahapan di mana masingmasing tahapan membutuhkan sikap seperti ketelatenan, kesabaran dan kedisiplinan. Sehingga peserta memperoleh latihan dalam sikap dan mental secara tidak langsung. Hasil nyata dari kegiatan pelatihan ini adalah peserta memiliki keterampilan dalam membatik. Mereka memahami dan menguasai tahapan demi tahapan proses mulai dari memindahkan desain sampai hasil yaitu produk batik.

\section{SIMPULAN}

Membatik merupakan bentuk kegiatan berkesenian yang membutuhkan olah rasa, cipta dan karsa. Pada saat sekarang keterampilan ini sudah memasuki semua lapisan dan kalangan masyarakat, tanpa terkecuali. Tidak saja dilakoni oleh masyarakat di mana seni membatik ini tumbuh dan berkembang, akan tetapi tempat di mana belum dikenal sekalipun, kegiatan ini dapat diterima dengan baik. Seperti halnya di Sekolah Luar Biasa Negeri 1 Padangpanjang dengan para anak didik yang memiliki Hal|79 keterbatasan (Anak Berkebutuhan Khusus). Pelatihan dilakukan terhadap para anak didik dengan beragam kekurangan fisik dan mental. Ditujukan secara keilmuan, mereka memiliki skill atau keterampilan yang dapat diaplikasikan di tengah masyarakat. Sedangkan secara mental, seni membatik dapat melatih kepekaan rasa, kesabaran dan ketelatenan, serta dapat merangsang perkembangan otak.

Anak Berkebutuhan Khusus atau disabilitas dengan berbagai kekurangan, ternyata memiliki kelebihan di balik itu. Kegiatan pelatihan, tidak begitu sulit bagi mereka dengan kekurangan yang dimiliki. Sementara membatik bukanlah kegiatan yang dapat dikategorikan sederhana dan mudah. Dari beberapa proses dalam membatik, memang tidak seluruhnya dapat mereka kuasai, akan tetapi secara 
umum dapat mereka lakukan dengan

baik melalui pendampingan dan arahan yang maksimal.

\section{KEPUSTAKAAN}

Aep S. Hamidin, 2010, Batik Warisan

Budaya Asli Indonesia,
Yogyakarta: Narasi

Dharsono Sony Kartika, 2016, Kreasi Artistik Perjumpaan Tradisi Modern dalam Paradigma Kekaryaan Seni, Karanganyar: LPKBN Citra Sain.

Gustami, SP., 2008, Nukilan Seni Ornamen Indonesia, Yogyakarta: Jurusan Seni Kriya Fakultas Seni Rupa ISI Yogyakarta 